\title{
Plasma thyrotropin concentration in the male pig: profile from birth to puberty and the effect of season and social environment in the young adult
}

\author{
VL Trudeau ${ }^{*}$, JC Meijer 1 , JL Vandalem 2, LM Sanford 3 \\ 1 Department of Functional Morphology, University of Utrecht, 3508 TD Utrecht, The Netherlands; \\ 2 Institut de Pathologie, Centre Hospitalier Universitaire, B400 Sart Tilman, Liège, Belgium; \\ ${ }^{3}$ Department of Animal Science, McGill University, Ste Anne de Bellevue, \\ Québec, Canada H9X 1 CO
}

(Received 30 July 1989; accepted 21 January 1991)

\begin{abstract}
Summary - Plasma thyrotropin (TSH) secretion was studied in crossbred (Landrace $x$ Large White) immature and young adult Landrace male pigs. Levels of TSH were low over the first 9 wk post-natally and were maximal at 12 wk of age. Thereafter, hormone levels declined and by 16 wk returned to values similar to those at $7 \mathrm{wk}$. In addition, a transient increase in TSH was noted at 22 wk. A second experiment involved 2 groups of young adult boars housed either in a socially nonrestrictive environment (adjacent to estrual females) or a socially restrictive environment (not in direct physical contact with females). TRH stimulated secretion of TSH and the magnitude of this response was affected by month; minimum and maximum responses were found in May and August respectively. There was an effect of social environment on TRH-induced TSH secretion; during February and August, the magnitude of the TSH response to TRH was lower in socially restricted than in socially non-restricted boars.
\end{abstract}

thyrotropin / TRH / male / pig

Résumé - Concentration plasmatique de thyrotropine chez le verrat: profll en cours de croissance; effet de la saison et de l'environnement social chez le jeune adulte. Les taux plasmatiques d'hormone thyréostimulante (TSH) ont été étudiés chez les verrats croisés (Landrace $x$ Large White) immatures et Landrace matures. Le niveau de TSH est bas pendant les 9 premières semaines après la naissance puis s'élève jusqu'à la $12^{\circ}$ semaine. La concentration de TSH diminue ensuite progressivement jusqu'à la $16^{\theta}$ semaine et une seconde augmentation transitoire de TSH est observée à 22 semaines. Une expérimentation a été réalisée sur 2 groupes de verrats adultes maintenus dans un environnement social différent : soit près de femelles en chaleurs, soit dans un environnement social restreint, sans contact direct avec des femelles. La sécrétion de TSH est stimulée par une injection de TRH. L'intensité de la réponse à TRH change selon les mois (minimum en mai et maximum en août) et l'environnement social (elle est plus basse chez les verrats en environnement social restreint que chez les autres verrats aux mois de février et août).

hormone thyréostimulante / TRH / verrat

* Correspondence and reprints: Department of Zoology, University of Alberta, Edmonton, Alberta, Canada T6G 2E9 


\section{INTRODUCTION}

Thyroid hormones are known to have an important role in both somatic growth and in development of the central nervous system in mammalian species (Schwartz, 1983). The ontogeny of the hypothalamohypophysial-thyroid axis has been studied in man, sheep and the rat (Fisher et al, 1977; Strbak and Michalickova, 1984; Roti, 1988). However, little information exists with respect to the functional development of the hypophysial-thyroid axis of the pig.

In the pig, thyrotropin (TSH) has been detected by immunocytochemistry (Dacheux and Martinat, 1983) as early as $45 d$ post-coitum $(\mathrm{pc})$ and pituitary TSH content increases progressively from $95 \mathrm{~d} p c$ to 50 $d$ of post-natal life (McNamara et al, 1986). The hypophysial-thyroid axis becomes functional during the fetal period since thyrotropin-releasing hormone (TRH) stimulates TSH release in late gestational fetuses (Parvizi et al, 1979) and fetal decapitation impairs thyroid gland development and reduces serum thyroxine (T4) concentrations (Fentener van Vlissingen et al, 1983). The post-natal pattern of TSH secretion has not been documented for the pig.

Seasonal variations in hypophysialthyroid function have been reported for several mammalian species (ie whitetailed deer: Bubenik and Bubenik, 1978; squirrel monkey: Kaack et al, 1980; rat: Wong et al, 1983; human: Konno and Morikawa, 1982). There has been no report of seasonal variation in hypophysial-thyroid function in domestic swine but it is known that blood levels of luteinizing hormone (Trudeau and Sanford, 1990), prolactin (PRL; Trudeau et al, 1988a), growth hormone (Trudeau et al, 1988b); and gonadal steroids (Claus et al, 1985) vary annually in male pigs. The social environement in which male pigs are housed also affects reproductive hormone levels (Trudeau et al, 1988a; Trudeau and Sanford, 1990) and may therefore also influence plasma $\mathrm{TSH}$.

The first objective of the present study was to extend our studies on functional development of the porcine hypothalamohypophysial axis (Colenbrander et al, 1982; Meijer et al, 1985, 1988) to include plasma TSH profiles. The second objective was to investigate the influence of season and social environment on TSH secretion in male pigs. The data characterize the post-natal profile of circulating TSH in the immature male pig and the effect of season and social environment on plasma TSH concentration and on the TSH response to exogenous TRH in the young adult male pig.

\section{MATERIALS AND METHODS}

\section{Animals and experimental protocol}

\section{Immature animals}

Blood was collected at weekly or biweekly intervals by jugular puncture from 11 male crossbred Dutch Landrace $\times$ Large White pigs (housed at the University of Utrecht, The Netherlands) between 1 and 17 wk of age and 6 of these individuals were sampled until 28 wk. All blood samples were taken between 10 and $11 \mathrm{~h}$ on a given collection day. Plasma was harvested by centrifugation within $2 \mathrm{~h}$ of collection and stored at $-70^{\circ} \mathrm{C}$ until assayed for $\mathrm{TSH}$. All animals were born in mid-February and were exposed to the natural daylength changes of The Netherlands. All animals had epididymal sperm (data not included) at the termination of the experiment ( $30 \mathrm{wk}$ of age) and were therefore considered to have reached puberty by this time. 


\section{Young adult animals}

Eight purebred Landrace boars (housed at McGill University, Canada) approximately 12 months of age were kept in a socially nonrestrictive or socially restrictive environment for a 12-month period beginning in September. A detailed description of these environments has been previously reported (Trudeau and Sanford, 1986). Boars were considered sexually experienced since semen was collected weekly using a dummy sow.

During the months of February, May and August, a jugular vein in each boar was cannulated for serial blood collection before and following intravenous (iv) injection of TRH $(1 \mu \mathrm{g} / \mathrm{kg})$ as previously described (Trudeau et al, 1988a).

\section{Radioimmunoassay (RIA) of TSH}

Plasma samples (100-200 $\mu \mathrm{l})$ were assayed in duplicate by homologous pTSH RIA (Vandalem et al, 1975) except that ${ }^{125}$-I-labelled PTSH was prepared by the iodogen method described by McNamara et al (1986). Within and between assay variances were $<10 \%$ and the minimum detection limit ranged between $0.15-0.30 \mathrm{ng} / \mathrm{ml}$. Plasma levels of thyroid hormones were not measured due to insufficient plasma volume remaining after TSH RIA.

\section{Data and statistical analysis}

TSH profiles (ie the effect of age on plasma TSH levels) in immature boars were analyzed using the least squares method of analysis of variance (AOV) of Statistical Analysis Systems (SAS), General Linear Models procedures (Barr et al, 1979). Data were analyzed with age and pig as variables. Following AOV, comparisons between ages were made using the least squares means (LSM).

The TSH response to TRH in young adult males was characterized as follows. The mean of the 7 samples collected at 20-min intervals before TRH injection was considered to represent basal concentration. Peak height was the highest value associated with the response curve; subtraction of basal concentration from peak height yielded the delta value. Time of the peak was recorded in min. Basal TSH concentrations and the TSH response to TRH were analyzed by AOV. The model included the effects of month, social environment and the month $x$ social environment interaction. The social environment effect was tested using the boar-withinsocial environment mean square while the effect of month and the month $x$ social environment interaction were tested with the residual mean square. Following AOV, comparisons between social environments and months were made using the LSM.

\section{RESULTS}

In the immature boars, plasma concentrations of TSH varied considerably $(P<0.01)$ between 1 and 28 wk of age. Two peaks of TSH secretion were present (fig 1; peaks are indicated by ${ }^{*}$ ). Levels of TSH did not vary significantly over the first 9 wh of age but rose to maximal values between 9 and 12 wk of age and declined thereafter. By 16 wk TSH levels were comparable to those at 7 wk. A second smaller peak in plasma TSH $(P<0.05$ compared to 20 or 24 wk) was noted at 22 wk of age.

In socially restricted boars, basal TSH concentrations (table I) did not vary significantly between months $(P>0.05)$; however, in socially non restricted boars, levels of TSH were $31 \pm 14 \%(P<0.05 ; n=4)$ lower in May than in February. Intravenous injection of TRH induced TSH release; TSH concentration peaked between 15-40 min following TRH injection and returned to basal levels within 60-120 min (fig 2). Time of peak response was not affected $(P>0.05)$ either by month of the year or social environment. The net increase in TSH above basal levels (delta value) varied between months $(P<0.01)$; minimum and maximum values were observed in May and August, respectively. There was an effect of social environment $(P<0.01)$ with delta values in February and August 


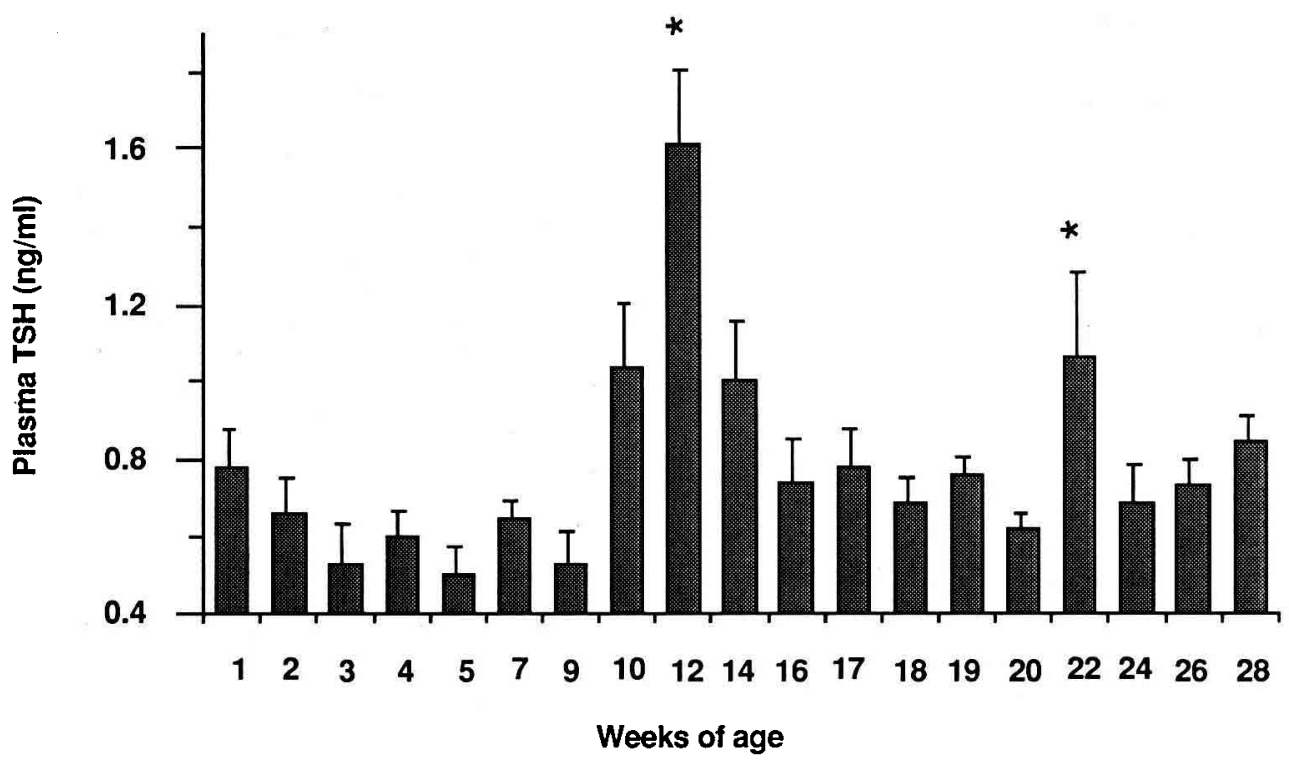

Fig 1. Plasma TSH concentrations $(\mathrm{ng} / \mathrm{ml})$ in immature boars between 1 and 28 wk of age. Means $( \pm$ SEM) represent 11 animals from $1-17$ wk and 6 animals thereafter. Plasma TSH concentrations statistically $(P<0.05)$ higher than preceding basal levels are indicated by *.

Table I. Serum TSH characteristics before and following iv injection of TRH ( $1 \mu \mathrm{g} / \mathrm{kg}$ body weight) in socially non-restricted and socially restricted boars in February, May and August.

\begin{tabular}{lccc}
\hline & Feb & May & Aug \\
\hline Basal concentration $(\mathrm{ng} / \mathrm{ml})$ & & & \\
$\quad$ Non-restricted & $0.50 \pm 0.25^{\mathrm{a}}$ & $0.24 \pm 0.04^{\mathrm{b}}$ & $0.33 \pm 0.09^{\mathrm{ab}}$ \\
$\quad$ Restricted & $0.41 \pm 0.11^{\mathrm{a}}$ & $0.27 \pm 0.05^{\mathrm{ab}}$ & $0.38 \pm 0.13^{\mathrm{ab}}$ \\
$\begin{array}{l}\text { Delta value }(\mathrm{ng} / \mathrm{ml}) \\
\quad \text { Non-restricted }\end{array}$ & $0.40 \pm 0.04^{\mathrm{b}}$ & $0.25 \pm 0.01^{\mathrm{cd}}$ & $0.70 \pm 0.10^{\mathrm{a}}$ \\
$\quad$ Restricted & $0.19 \pm 0.02^{\mathrm{d}}$ & $0.16 \pm 0.05^{\mathrm{d}}$ & $0.35 \pm 0.04^{\mathrm{bc}}$ \\
$\quad$ & & \\
$\quad$ Time of peak (minutes) & & & \\
$\quad$ Non-restricted & $17.5 \pm 4.8^{\mathrm{a}}$ & $22.5 \pm 9.5^{\mathrm{a}}$ & $22.5 \pm 12.5^{\mathrm{a}}$ \\
$\quad$ Restricted & $17.5 \pm 2.5^{\mathrm{a}}$ & $35.0 \pm 5.0^{\mathrm{a}}$ & $22.5 \pm 6.3^{\mathrm{a}}$ \\
\hline
\end{tabular}

Note: means ( \pm SEM) represent values from 4 boars. For a given characteristic, means followed by the same letter are not significantly $(P>0.05)$ different (least squares method of analysis of variance). Basal concentration is the mean of 7 samples collected at 20 -min intervals before TRH injection. Delta value is the highest TSH concentration following TRH injection minus basal concentration. 


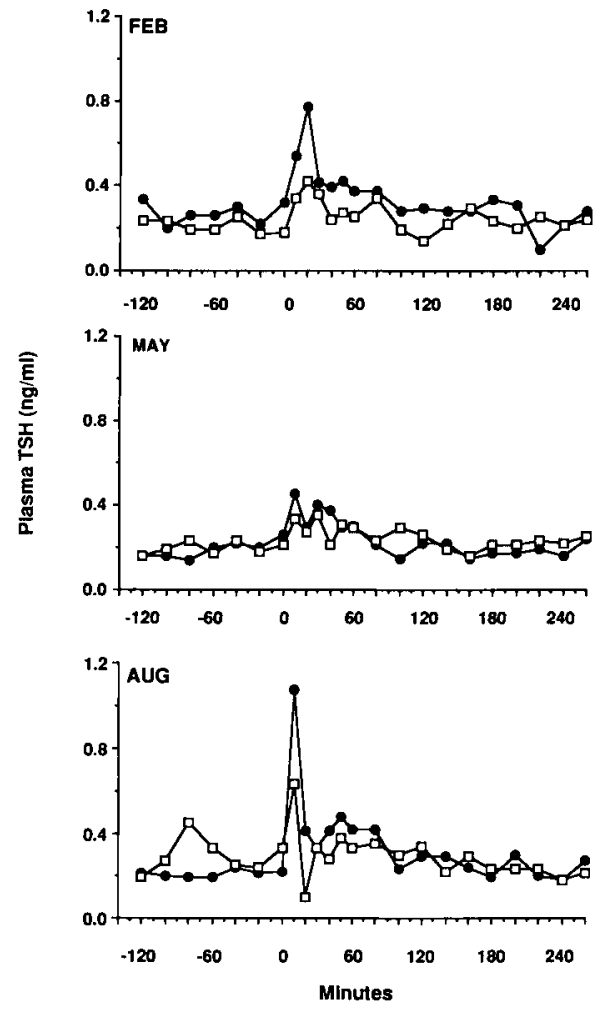

Fig 2. Serum TSH secretory profile of boar 3 (socially non-restricted; solid circles) and boar 32 (socially restricted; open squares) in February, May and August. TRH (1 $\mu \mathrm{g} / \mathrm{kg}$ iv) was injected at time 0 .

being approximately $50 \%$ lower in socially restricted than in socially non-restricted boars.

\section{DISCUSSION}

Levels of TSH in the postnatal period decreased slightly from 1 to $5 \mathrm{wk}$ and increased at 12 wk (see fig 1). The augmentation of plasma TSH at 12 wk represented approximately a 2.5-3-fold increase over levels at 4-5 wk of age. Thereafter, plasma TSH concentrations declined until 22 wk when a transient increase was observed.

The mechanisms underlying these changes in TSH in male pigs are not known. In the maturing rat, however, the TSH response to TRH decreases progressively and the negative feedback sensitivity of TSH to thyroid hormones increases (Fisher et al, 1977) during periods of declining TSH secretion. Pituitary TSH content increases progressively during the neonatal period (Mc Namara et al, 1986) suggesting that declining plasma TSH in the first 5 wk of post-natal life could have resulted from altered pituitary sensitivity to $\mathrm{TRH}$ and/or changes in the negative feedback effects of thyroid hormones. Furthermore, the peak in TSH secretion between 10 and 14 wk could also result from decreasing feedback inhibition and/or increasing stimulation of hormone release. The decline in TSH levels after 12 wk corresponds to a period when maximal $\mathrm{T}_{4}$ concentrations were noted in barrows and gilts (Marple et al, 1981). Additionally, $\mathrm{T}_{4}$ declines between 18 and 22 wk (Marple et al, 1981) when we observed an increase in TSH. Maturational changes in other stimulatory and inhibitory factors (see Simpkins, 1982; Hershman and Pekary, 1985; Roti, 1988 for examples) known to influence TSH secretion may have contributed to the observed variations in plasma TSH, but their role(s) in the neuroendocrine regulation of TSH secretion in the pig has not been established.

Thyroid hormones have a role in the reproductive physiology of male mammals (see Maqsood, 1952; Chandrasekar et al, 1985). Administration of $T_{4}$ results in precocious sexual development in several mammalian species (Maqsood, 1952). Heightened pituitary TSH secretion at 12$14 \mathrm{wk}$, which corresponds to a maturational phase when rapid testicular growth is expected (van Straaten and Wensing, 1977; Allrich et al, 1983) may be indicative 
of a relationship between pituitary-thyroid function and sexual development in the male pig. An increase in plasma TSH could also conceivably contribute to Sertoli cell development since TSH can stimulate cellular activity in the immature animal (Hutson and Stocco, 1981).

In adult male pigs the TSH response to TRH was reduced in May and particularly high in August. Seasonal variatons in the negative effects of thyroid hormones and/ or somatostatin may contribute to changes in TRH sensitivity since they are known to reduce the TSH response to TRH (Simpkins, 1982; Hershman and Pekary, 1985). The seasonal pattern of thyroid hormone secretion has not been documented for the pig. Alternatively, it is known that gonadal steroids influence the TSH response to TRH (Simpkins, 1982; Hershman and Pekary, 1985). Increased levels of testosterone and/or estradiol (Claus et al, 1985; Trudeau and Sanford, 1990) in August may have potentiated the release of TSH following $\mathrm{TRH}$ injection. Additionally, both TSH (this study) and PRL (Trudeau et al, 1988a) response to TRH are increased in August suggesting that a control mechanism common to both hormones is altered at this time. Although these animals were exposed to seasonal variations in both daylength and ambient temperature (Trudeau and Sanford, 1990), there is no obvious relationship between these factors and variations in TSH secretion. More detailed studies will be necessary to establish which environmental factor is responsible for seasonal changes in TRHstimulated TSH secretion. Furthermore, given the ages of the young adult boars in this study, some influence of maturation on the results cannot be excluded. Howev$\mathrm{er}$, in the adult ram, TSH response to exogenous TRH does not change between 1-5 yr of age (Morrison et al, 1981) sug- gesting that this response is stable during early adult life.

The presence or absence of female pigs influenced TRH-induced TSH secretion in the young adult boars; this was evident in both February and August. This observation is intriguing, but the reasons for this effect are unknown. Differences in levels of gonadal steroids were not likely involved, since both groups had similar testosterone levels at these times (Trudeau and Sanford, 1990). Although copulation in the female rabbit results in decreased pituitary TSH content and unchanged TSH secretion (Brown-Grant et al, 1968), the effects of sexual stimulation on TSH secretion in males is unknown.

\section{CONCLUSION}

In summary, this study is the first to demonstrate that circulating TSH levels vary throughout the first 28 wk of like in the domestic male pig. In addition, TRH stimulates TSH secretion in the young adult $(>1$ $\mathrm{yr}$ of age) and the response varied between seasons and was affected by social environment. How these effects are mediated is not known and warrants further investigation.

\section{REFERENCES}

Allrich RD, Christenson RK, Ford JJ, Zimmerman DR (1983) Pubertal development of the boar: age-related changes in testicular morphology and in vitro production of testosterone and estradiol-17B. Biol Reprod 28, 902909

Barr AJ, Goodnight JH, Sall JP, Helwig JT (1979) SAS User's Guide. SAS Institute, Raleigh, North Carolina

Brown-Grant K, El Kabir DJ, Fink G (1968) The effect of mating on pituitary luteinizing hor- 
mone and thyrotropin hormone content in the female rabbit. $J$ Endocrinol 41, 91-94

Bubenik GA, Bubenik AB (1978) Thyroxine levels in male and female white-tailed deer (Odocoileus virginianus). Can J Physiol Pharmacol 56, 945-949

Chandrasekhar Y, Holland MK, D'Occhio MJ, Setchell BP (1985) Spermatogenesis, seminal characteristics and reproductive hormone levels in mature rams with induced hypothyroidism and hyperthyroidism. $J$ Endocrinol 105, 39-46

Claus A, Schopper D, Wagner HG, Weiler U (1985) Photoperiodic influences on reproduction of domestic boars. 1. Light influences on testicular steroids in peripheral blood plasma and seminal plasma. Zentralbl Veterinaermed Reihe A 32, 99-109

Colenbrander $B$, Frankenhuis $M$, Wensing $C$ (1982) Male sexual development. In: Control of Pig Reproduction (Cole DJA, Foxcroft GR, eds) Butterworth Scientific, London, 3-24

Dacheux F, Martinat N (1983) Immunocytochemical localization of $\mathrm{LH}, \mathrm{FSH}$ and $\mathrm{TSH}$ in the fetal porcine pituitary. Cell Tissue Res $228,277-295$

Fentener van Vlissingen JM, Colenbrander $B$, Wensing CJG (1983) Morphological development of the thyroid gland and serum $\mathrm{T}_{4}$ concentration in the intact and decapitated pig fetus. J Dev Physiol 5, 361-371

Fisher DA, Dussault JH, Sack J, Chopra I (1977) Ontogenesis of hypothalamicpituitary-thyroid function and metabolism in man, sheep and rat. Recent Prog Horm Res 33, 59-107

Hershman JM, Pekary AE (1985) Regulation of thyrotropin secretion. In: The Pituitary Gland (Imura H, ed) Raven Press, New York, 149188

Hutson JC, Stocco DM (1981) Regulation of Sertoli cell function by thyrotropin. Biol Reprod 25, 303-306

Kaack M, Walker M, Walker L (1980) Seasonal changes in the thyroid hormones of the male squirrel monkey. Arch Androl 4, 133-136

Konno N, Morikawa K (1982) Seasonal variation of serum thyrotropin concentration and thyrotropin response to thyrotropin-releasing hormone in patients with primary hypothyroidism on constant replacement dosage of thyroxine. J Clin Endocrinol Metab 54, 1118 1124

Maqsood M (1952) Thyroid function in relation to reproduction of mammals and birds. Biol Rev 27, 281-319

Marple DN, Nachreiner RF, Prichett JF, Kuhlers DL (1981) The relationship of thyroxine secretion rate to growth of swine. I Anim Sci $52,500-504$

McNamara M, Vandalem JL, Hennen G, Colenbrander B, McDonald AA, van de Wiel D, Meijer J (1986) Ontogeny of hypothalamicpituitary function in the pig: pituitary thyrotropin in the fetus and neonate. $J$ Endocrinol 111,111-115

Meijer JC, Colenbrander B, Poot P, Wensing CJG (1985) Development of pituitary gonadotropic cells in the pig fetus and the effect of luteinizing hormone-releasing hormone administration. Biol Reprod 32, 137-143

Meijer JC, Trudeau VL, Colenbrander B, Poot P, Erkens JHF, Van de Wiel DFM (1988) Prolactin in the developing pig. Biol Reprod 39, 264-269

Morrison MW, Davis SL, Spicer LJ (1981) Ageassociated changes in secretory patterns of growth hormone, prolactin and thyrotropin and the hormonal responses to thyrotropinreleasing hormone in rams. $J$ Anim Sci 53, $160-170$

Parvizi N, McDonald AA, Ellendorff F (1979) TSH secretion in the pig: effects of thyroidetomy and $\mathrm{TRH}$ injection in chronically catheterized fetuses. Acta Endocrinol (suppl) 225, 29

Roti E (1988) Regulation of thyroid-stimulating hormone (TSH) secretion in the fetus and neonate. J Endocrinol Invest 11, 145-158

Simpkins JW (1982) Regulation of thyroidstimulating hormone secretion. In: Handbook of Endocrinology (Gass GH, Kaplan HM, eds), CRC Press, Boca Raton, 61-69

Schwartz HL (1983) Effects of thyroid hormone on growth and development. In: Molecular Basis of Thyroid Hormone Action (Oppenheimer $\mathrm{JH}$, Samuels $\mathrm{HH}$, eds) Academic Press, New York, 413-444

Strbak V, Michalickova J (1984) Hypothalamicpituitary-thyroid system during suckling period in rat and man. Endocrinol Exp 18, 183196 
Trudeau V, Sanford LM (1986) Effect of season and social environment on testis size and semen quality of the adult Landrace boar. $J$ Anim Sci 63, 1211-1219

Trudeau V, Sanford LM (1990) Influence of season and social environment on the reproductive-endocrine status of the adult Landrace boar. Can J Anim Sci 70, 121-128

Trudeau VL, van de Wiel DFM, Erkens J, Sanford LM (1988a) Influence of season and social environment on basal and thyrotropin releasing hormone-induced prolactin secretion in the adult domestic boar. Acta Endocrinol 118, 277-282

Trudeau VL, Sanford LM, Bevers MM, Meijer JC (1988b) Serum growth hormone and corticosteroid concentrations in the adult boar vary with season. IRCS Med Sci Res 16, 1009-1010

Vandalem JL, Ketelslegers JM, Pirens G, Closset JA, Hennen G (1975) Dosage radioimmunologique de l'hormone thyréostimulante: étude immunologique du système et application clinique. Acta Clin Belg 30, 521-537

Van Straaten HWM, Wensing CJG (1977) Histomorphometric aspects of testicular morphogenesis in the pig. Biol Reprod 17, 467-472

Wong CC, Dohler KD, Atkinson MJ, Geerlings $H$, Hesch RD, von zur Muhlen A (1983) Circannual variations in serum concentrations of pituitary, thyroid, parathyroid, gonadal and adrenal hormones in male laboratory rats. $J$ Endocrinol 97, 179-185 